\title{
Psychiatric referral of patients in a venereal diseases clinic
}

\author{
J. R. PEDDER
}

Academic Department of Psychiatry, The Middlesex Hospital, London, W.1

A NEW department for patients with venereal and sexually-transmitted diseases, James Pringle House, was opened in 1965 at the Middlesex Hospital, and psychiatric investigation has been regularly available since December, 1967. This follows the general policy at the Middlesex, where a member of the department of psychiatry is attached to each department of the general hospital; and accords with the specific recommendations (Pahmer, 1949; Mayer-Gross, Slater, and Roth, 1960) that venereology clinics in particular need to have a psychiatrist available within the same premises. The criteria for referral were not specified and are clearly as various as the psychiatric attitudes of the many doctors working in the clinic. This report is a first impression gained under the conditions outlined, and is by no means a comprehensive survey of the extent of psychiatric disturbance in patients attending this clinic.

Several earlier studies of psychiatric disturbance in patients attending venereology clinics have been concerned with the problem of morbid fears of venereal disease. A study of patients presenting with overt syphilophobia (Macalpine, 1957) was prompted by the finding that half of the patients in a dermatology department with intractable pruritus ani feared they had syphilis. She found syphilophobia to be a symptom accompanying or preceding all stages and categories of mental illness; all her patients had previously attended other venereology clinics and had an average of six negative results to serum tests for syphilis. The report of Gibbens and Silberman (1960) arose from an inquiry, undertaken before the passage of the Street Offences Act, into the nature of the demand for prostitution. Of 230 patients from a venereology clinic who were interviewed, 30 per cent. did not have venereal disease but feared they had.

Kite and Grimble (1963) were concerned with the extent to which fear of venereal disease may be

Received for publication June 6, 1969 aroused by anti-V.D. propaganda. Like Macalpine $\vec{T}$ they found venereophobia to be associated with a wide $\frac{\mathbb{O}}{O}$ range of psychiatric disorders. Out of 76 consecutive psychiatric referrals, 32 patients in nine different diagnostic categories, most commonly endogenous $\vec{P}$ depression, had a phobia of venereal disease as their most prominent symptom.

\section{Present findings}

The present report reviews the findings in forty new cases (29 men and 11 women) referred for psychiatric opinion over a period of 16 months. This is a minute $\stackrel{\mathbb{Q}}{\varrho}$ fraction of all new patients seen during this time at $\overrightarrow{\vec{A}}$ James Pringle House: approximately 0.35 per cent. $\leftrightarrows$ of the men and 0.3 per cent. of the women. The age range, marital status, nationality, and venereologicalọ. diagnosis of the patients (Tables I, II, III, and IV) are closely similar to those of the total population attending the clinic.

T A B L I Age of patients, by sex

\begin{tabular}{|c|c|c|c|c|c|c|}
\hline Age & $\begin{array}{l}\text { Under } \\
20\end{array}$ & $20-29$ & $30-39$ & $40-49$ & $\begin{array}{l}50 \\
\text { and over }\end{array}$ & $\begin{array}{l}\text { All } \\
\text { ages }\end{array}$ \\
\hline $\begin{array}{l}\text { Male } \\
\text { Female }\end{array}$ & $\begin{array}{l}2 \\
0\end{array}$ & $\begin{array}{r}12 \\
7\end{array}$ & $\begin{array}{r}13 \\
1\end{array}$ & $\begin{array}{l}2 \\
2\end{array}$ & $\begin{array}{l}0 \\
1\end{array}$ & $\begin{array}{l}29 \\
11\end{array}$ \\
\hline Total & 2 & 19 & 14 & 4 & 1 & 40 \\
\hline
\end{tabular}

TABLE I I Marital status, by sex

\begin{tabular}{|c|c|c|c|}
\hline Marital status & Single & Married & Separated or Divorced \\
\hline $\begin{array}{l}\text { Male } \\
\text { Female }\end{array}$ & $\begin{array}{r}23 \\
6\end{array}$ & $\begin{array}{l}6 \\
2\end{array}$ & $\begin{array}{l}0 \\
3\end{array}$ \\
\hline Total & 29 & 8 & 3 \\
\hline
\end{tabular}

T A B LE I I I Country of origin, by sex

\begin{tabular}{llll}
\hline Country of origin & & British Isles & All others \\
\cline { 3 - 4 } Male & & 21 & 8 \\
Female & & 9 & 2 \\
\cline { 3 - 4 } Total & 30 & 10 \\
\hline
\end{tabular}


TAB LE IV Venereological diagnoses

\begin{tabular}{|c|c|c|c|c|}
\hline \multicolumn{2}{|l|}{ Sex } & \multirow{2}{*}{$\begin{array}{l}\text { Male } \\
8\end{array}$} & \multirow{2}{*}{$\begin{array}{l}\text { Female } \\
3\end{array}$} & \multirow{2}{*}{$\frac{\text { Total }}{11}$} \\
\hline Diagnosis & $\begin{array}{l}\text { No sexually-transmitted } \\
\text { disease }\end{array}$ & & & \\
\hline & $\begin{array}{l}\text { Non-specific } \\
\text { urethritis/cervicitis }\end{array}$ & 11 & 1 & 12 \\
\hline & Gonorrhoea & 4 & 3 & 7 \\
\hline & Miscellaneous & 6 & 4 & 10 \\
\hline & All diagnoses & 29 & 11 & 40 \\
\hline
\end{tabular}

Table $\mathrm{V}$ lists the psychiatric diagnoses of the cases referred. Some of these are merely descriptive categories and need further explanation. 'Isolated Sexual Problem' includes patients with varying problems of potency who did not acknowledge any other difficulties in their lives. Many authorities would agree with Stafford-Clark (1954) that the majority of such cases are psychological in origin; but others would support the view of Johnson (1965) that there may be a constitutional basis. Since either view involves an assumption, a merely descriptive diagnosis has been made here. Secondly, the current psychiatric trend is to regard hypochondriasis not as a separate diagnostic entity but as a symptom, most often of an underlying depressive condition, as argued by Kenyon (1965). But patients appear in venereology clinics for whom this still seems the best descriptive diagnosis and who do not appear to have any accompanying disorder. Thirdly, two married male patients were seen complaining of symptoms after intercourse, usually referable to the abdomen or gastrointestinal tract, which were thought to be functional in origin. These symptoms were used as a reason for avoiding intercourse, and were comparable to some cases of dyspareunia in women; in both there were underlying marital problems, but the presenting complaints had

\section{TABLE V Psychiatric diagnoses}

\begin{tabular}{|c|c|c|c|c|c|}
\hline \multicolumn{3}{|l|}{ Sex } & \multirow{2}{*}{$\frac{\text { Male }}{14}$} & \multirow{2}{*}{ Female } & \multirow{2}{*}{$\begin{array}{l}\text { Total } \\
21\end{array}$} \\
\hline \multirow[t]{8}{*}{ Diagnosis } & \multicolumn{2}{|c|}{$\begin{array}{l}\text { Personality disorder } \\
\text { (including } \\
\text { homosexuality) }\end{array}$} & & & \\
\hline & $\begin{array}{l}\text { Affective } \\
\text { disorder }\end{array}$ & $\begin{array}{l}\text { Anxiety } \\
\text { Depression }\end{array}$ & $\begin{array}{l}2 \\
0\end{array}$ & $\left.\begin{array}{l}0 \\
4\end{array}\right\}$ & 6 \\
\hline & \multicolumn{2}{|c|}{ Isolated sexual problem } & 5 & 0 & 5 \\
\hline & \multicolumn{2}{|c|}{ Hypochondriasis } & 3 & 0 & 3 \\
\hline & \multicolumn{2}{|c|}{ Post-coital symptoms } & 2 & 0 & 2 \\
\hline & \multicolumn{2}{|c|}{ Schizophrenia } & 1 & 0 & 1 \\
\hline & \multicolumn{2}{|c|}{ Subnormality } & 1 & 0 & 1 \\
\hline & \multicolumn{2}{|c|}{ Drug addiction } & 1 & 0 & 1 \\
\hline
\end{tabular}

become so much the focus of attention and taken both patients to so many doctors in search of a physical cause that the descriptive diagnosis of 'post-coital symptoms' has been given.

Of the fourteen men with personality disorders, twelve were homosexuals though not all were seeking help for their sexual orientation. The two men with anxiety states were also homosexual, both in an acute state of anxiety about their abnormality.

The immediate outcome and disposal after psychiatric referral are shown in Table VI. The largest group was that of patients seen only once. Sometimes this was because language barriers made it impossible to proceed further or because the patient was already under psychiatric treatment elsewhere. More often it was because the patient did not really want psychiatric help or because one interview had helped to clarify the problem. Patients who wanted further long-term help were referred either for psychotherapy or behaviour therapy, usually after a second interview and a discussion about which they felt was most likely to meet their needs; all the men in this category were homosexuals. Some of these patients did not keep even the first appointments made for them, and only one pursued the treatment offered. Of the six patients who improved with drug treatment, five had affective disorders and one post-coital symptoms.

\section{TABLE VI Disposal after psychiatric referral}

\begin{tabular}{|c|c|c|c|c|}
\hline \multicolumn{2}{|l|}{ Sex } & \multirow{2}{*}{ Male } & \multirow{2}{*}{$\frac{\text { Female }}{3}$} & \multirow{2}{*}{$\frac{\text { Total }}{14}$} \\
\hline Disposal & One interview only & & & \\
\hline & $\begin{array}{l}\text { Offered } \\
\text { treatment } \\
\text { and failed }\} \text { Psychotherapy } \\
\text { Behaviour } \\
\text { therapy }\end{array}$ & $\begin{array}{l}3 \\
2\end{array}$ & 3 & 6 \\
\hline & Improved with drugs & 3 & 3 & 6 \\
\hline & $\begin{array}{l}\text { Failed before treatment } \\
\text { established }\end{array}$ & 5 & 2 & 7 \\
\hline & Still under treatment & 4 & 0 & 4 \\
\hline & $\begin{array}{l}\text { Addict referral to special } \\
\text { clinic }\end{array}$ & 1 & 0 & 1 \\
\hline
\end{tabular}

\section{Discussion}

Kite and Grimble (1963) found a higher proportion of patients with no sexually-transmitted disease, but this may only reflect interest in patients with venereophobia. Their commonest psychiatric diagnosis was affective disorder whereas in this study it was personality disorder; this may reflect different diagnostic habits. The categories of personality and affective disorder, taken together, include about two-thirds of the patients in both studies. However, this may be minimizing the differences. The patients here diagnosed as having personality disorders all had long- 
term difficulties which were more prominent than any current affective disturbance; and most of the men were homosexuals.

Kite and Grimble's finding that the prognosis in cases of affective disorder is excellent has been confirmed. They reported venereophobia to be most frequently associated with cases of endogenous depression. Though the numbers here are too small to be significant, this finding is supported in that the two severest cases of depression, both in women, presented with unfounded fear of venereal disease. That a fear of venereal disease, especially in a person who has not recently had intercourse, may be a symptom of a severe depressive condition is not yet widely recognized. Kite and Grimble found that 78 per cent. of their patients with venereophobia gave anti-V.D. propaganda as the main cause of their fear, and though the authors appeared to agree with the patients that this was an important factor, they expressed surprise that this should be so when the prognosis for venereal disease is so good. An alternative explanation is that guilt and anxiety about sexual activity and phantasy and even a wish for punishment make some people far more susceptible to such fears than others. This is also suggested by the finding of Macalpine (1957) that, although all her patients gave a history of exposure, this was delusional or fictitious in half the cases.

Similarly, the two cases of suicide referred to by Kite and Grimble as examples of the consequences of fear of venereal disease have an alternative explanation; both appear to have been cases of depression with hypochondriacal fears about venereal disease as part of the content of the mental state. These two cases were among four reported in three letters to the British Medical fournal (Thyne, 1961; Dawid, 1961 ; Faull, 1961), all in ex-servicemen who developed fears of venereal disease despite repeated negative results to examinations. In the two cases reported by Thyne the fears began when the patients' children developed respiratory infections which they thought to be the result of inherited syphilis. Three of the four patients committed suicide. On the available details a more probable psychiatric explanation is that all these patients developed severe depressive conditions and that the fear of venereal disease was part of the content of the illness rather than its cause. Kite and Grimble's finding that venereophobia was commonest in cases of endogenous depression supports this view.

Venereologists often suggest that depression occurs as a response to the diagnosis of venereal disease. Thus Seale (1966) observed that the emotional reaction of wives of male patients with gonorrhoea was greater when they knew the diagnosis than when they did not. This reaction is readily understandableo because of the implications of the diagnosis in terms 으 of the husband's infidelity. However, Seale $\frac{\overline{\bar{p}}}{\bar{s}}$ generalizes from the reactions in contacts to the $\mathbb{\Phi}$ reactions in patients themselves and regards Kite and Grimble's statement that many of their patients had ${ }^{\text {क }}$ no previous psychiatric history as evidence supporting.

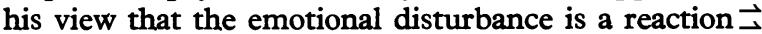
to the diagnosis of venereal disease. But since 87 per cent. of their patients had no venereal disease, this $\stackrel{?}{\longrightarrow}$ surely could not be so. My own view would be that, whereas some patients will certainly become de-? pressed following on learning the diagnosis, particu- $\overrightarrow{i r}$ larly because of the implications of infidelity within ${ }_{0}^{+}$ a relationship, others who come to V.D. clinics become depressed de novo and develop fears of $\vec{T}$ venereal disease just as severely depressed patients $\mathbb{D}$ may develop ideas of unpleasant diseases in other systems; most cases of suicide associated with venereophobia probably belong to this latter group. $\overrightarrow{0}$

As already mentioned, only one patient pursued the offer of further help by psychotherapy or behaviour therapy, so that the expectation that there might be a large number of patients with sexual problems, particularly homosexuals, wanting further help, which would be difficult to arrange, did not $\frac{\circ}{D}$ materialize. Of the fourteen male homosexuals seen, $\varrho$ two were in an acute anxiety state about their sexual $\overrightarrow{\overrightarrow{0}}$ orientation, but when this anxiety resolved with drugs 3 they did not want further help. Three were referred for psychotherapy and three for behaviour therapy, but only one of the latter pursued it. At the time of? referral two were emerging from a period of promiscuous homosexual activity and were already estab-3. lishing satisfying heterosexual relationships; they wanted reassurance that their homosexuality had not $₹$ been something innate that would inevitably recur.의 One was under treatment elsewhere and another failed to keep a second appointment. This experience confirms the finding of Fluker (1966) of very low motivation for treatment among homosexual patients. He reported that, out of 200 patients offered psychia- $N$ tric advice, only ten sought it and of these four N cancelled their first appointments.

The three male patients with hypochondriasis were all foreigners with a very limited command of English; $\mathbb{\mathbb { D }}$ all had been to numerous other doctors and psychia-trists seeking a physical basis for their many $\frac{0}{0}$ symptoms and in no case was there any readily $\frac{\vec{D}}{\mathrm{D}}$ apparent underlying affective disturbance likely to $\frac{\mathcal{Q}}{\mathbb{D}}$ respond to physical methods of treatment. These 2 patients are a particular problem in management. Their limited English probably contributed to their feeling of not being properly understood as well as? 
making any psychological exploration of the underlying nature of their prol.lem virtually impossible.

The forty new patients seen represented a very small percentage of all new patients attending the clinic, and since several appointments were unfilled it seems unlikcly that there exists an unsatisfied demand for more psychiatric referral.

If the true incidence of psychiatric disturbance is as low as 0.3 per cent., this is very different from the picture seen in general hospital out-patient clinics (Culpan, Davies, and Oppenheim, 1960) or in general practice (Council of the College of General Practitioners, 1958); one may speculate that many patients attending a V.D. clinic are acting out their conflicts and dissatisfactions rather than experiencing them inwardly. To look into this question further, a systematic survey of the extent of psychiatric disturbance in all new patients has been undertaken.

\section{Summary and conclusions}

Findings among forty new cases referred for psychiatric investigation within a venereology clinic are presented. The type of patient seen most frequently was a single British homosexual male, aged 20 to 40 years with non-specific urethritis or with no evidence of sexually-transmitted disease, who either did not want or did not pursue the offer of psychiatric help. This study confirms previous findings that motivation for help in the cases of homosexual patients is very low. It further confirms that prognosis is best in cases of affective disturbance. The problem of the depressed patient who may present with unfounded fears of venereal disease is emphasized. The apparent low incidence of psychiatric disturbance in venereal disease clinic patients is discussed. Further studies are being undertaken.

I am indebted to Prof. John Hinton and Dr. R. D. Catterall for their interest and helpful criticism.

\section{References}

Council of the College of General Practitioners (1958). Brit. med. F., 2, 585.

Culpan, R. H., Davies, B. M., and Oppenheim, A. N. (1960). Ibid., 1, 855.

DAWID, I. (1961). Ibid., 1, 507.

FaulL, D. C. (1961). Ibid., 1, 1247.

FLUKER, J. L. (1966). Brit. F. vener. Dis., 42, 48.

Gibbens, T. C. N., and Silberman, M. (1960). Ibid., 36, 113.

Johnson, J. (1965). F. psychosom. Res., 9, 195.

Kenyon, F. E. (1965). Brit. F. med. Psychol., 38, 117.

Kite, E. de C., and Grimble, A. (1963). Brit. F. vener. Dis., $39,173$.

Macalpine, I. (1957). Ibid., 33, 92.

Mayer-Gross, W., Slater, E., and Roth, M. (1960). 'Clinical Psychiatry', 2nd ed., p. 449. Cassell, London.

PAHMER, M. (1949). Brit. F. vener. Dis., 25, 124.

SEALE, J. R. (1966). Ibid., 42, 31.

STAFFORD-ClARK, D. (1954). Practitioner, 172, 397.

Thyne, G. G. (1961). Brit. med. F., 1, 206.

Investigation psychiatrique chez des malades d'une clinique vénéréologique. Observations sur quarante cas

SOMMAIRE

Les résultats de recherches effectuées chez quarante nouveaux malades d'une clinique vénéréologique adressés au psychiâtre, sont présentés. Le type de malade que l'on voit le plus fréquemment est celui d'un homosexual célibataire, britannique, âgé de 20 à $\mathbf{4 0}$ ans, présentant une urétrite non spécifique ou n'ayant aucun signe de maladie sexuelle et qui, ou ne désire pas, ou qui cesse de rechercher l'aide psychiâtrique. Cette étude confirme les constatation précédentes que le désir d'assistance est très faible chez les homosexuels. Il confirme en outre que le pronostic est le meilleur en cas de trouble affectif. On souligne la fréquence du problème du malade déprimé qui présente une crainte non fondée de maladie vénérienne.

On discute la faible incidence apparente des troubles psychiâtriques chez les malades des dispensaires antivénériens. Des études ultérieures sont en cours. 